\title{
The Contribution of Three-Dimensional Computerized Tomographic Angiography in the Head Positioning of the Patients with Middle Cerebral Artery Aneurysms
}

\section{Orta Serebral Arter Anevrizmaln Hastalarn Cerrahi Baş Pozisyonunun Belirlenmesinde 3 Boyutlu Bilgisayarl Tomografik Anjiyografinin Katkus}

Enis KURUOGLU, Kerameddin AYDIN, Abdullah MARANGOZ, Cengiz COKLUK

Ondokuzmayis University, School of Medicine, Department of Neurosurgery, Samsun, Turkey

Corresponding Author: Enis KURUOGLU / E-mail: drenis@hotmail.com

\begin{abstract}
Surgical intervention is a gold standard technique for ruptured and unruptured middle cerebral artery bifurcation aneurysm. Before surgical intervention it is necessary to know the three-dimensional shape, surgical position, projection and position of the aneurysm and the course of the parent artery. In a demonstrative case with middle cerebral artery aneurysm, using the OsiriX MD image processing software for DICOM images, it was demonstrated the position of the aneurysm neck, the projection of the aneurysm and the course of the M1 segment in relation with dynamic rotation and extension of the head. These dynamic videographic neuroradiological images may enhance the surgical anatomic perspective of the surgeon before the surgical intervention.
\end{abstract}

KEYWORDS: Middle cerebral artery, Surgical intervention, Three-dimensional image processing

öz

Kanamış ve kanamamış orta serebral arter birleşim yeri anevrizmalarında cerrahi girişim altın standarttır. Cerrahi girişimden önce anevrizmanın üç boyutlu şekli, cerrahi pozisyonu, anevrizmanın projeksiyonu ve parent arterin seyri bilinmelidir. Demonstratif bir olguda DICOM görüntüleri işlenerek ve OsiriX MD programı kullanılarak, anevrizma ve boyun pozisyonu, anevrizmanın projeksiyonu, M1 segmentinin dinamik baş rotasyonu ve ekstansiyonuna göre lokalizasyonu gösterilmiştir. Bu dinamik videografik nöroradyolojik görüntüler cerrahi anatomik perspektifin geliştirilmesine cerrahi öncesinde katkı sağlayacaktır.

ANAHTAR SÖZCÜKLER: Orta serebral arter, Cerrahi girişim, Üç boyutlu görüntü oluşturma

\section{INTRODUCTION}

Middle cerebral artery aneurysms make up $20-30 \%$ of all intracranial aneurysms. $80 \%$ of them are located at the bifurcation segment of the artery $(4,6)$. The current surgical approach for middle cerebral artery aneurysms can be performed via a standard pterional craniotomy. Careful and delicate dissection of the sylvian fissure starting from distal and continuing proximal is the next step after opening the dura mater. According to the classical description by Yaşargil, the patient is positioned supine with a three-point skeletal fixation device such as Mayfield-Kees. The head should be directed about 20 degrees vertex down, elevated slightly and rotated about 30 degrees to the contralateral side to bring the malar eminence to the superior point of the operating field (12). Standardized classical head positioning procedure in the patients with basal cerebral arterial aneurysms may be modified depending on the location of the aneurysm, projection of the aneurysm dome, and the course of the parent artery by using three-dimensional computerized tomographic image analyzing. In the present demonstrative case, using the three-dimensional computerized tomographic images, standard head positioning was modified to expose the $\mathrm{M} 1$ segment and neck of the aneurysm through without head extension in the safe clipping of the aneurysm neck. In this report, the details of the technique are presented.

\section{CASE REPORT}

A 62-year-old female patient presented to the neurosurgery department because of headache and dizziness for about three months. Three-dimensional computerized tomographic angiography revealed that a saccular aneurysm originating from left middle cerebral artery, $7.5 \times 9.5 \mathrm{~mm}$ in diameter with its anterior and lateral projections. Head positions and head extension and rotation angles were estimated by using OsiriX MD computer software (Figure 1). During the surgery the patient was in supine position on the operating table. The patient's head was fixed with three pins Mayfield head 
holder as 0 degree extension and 45 degree lateral rotation. Left pterional craniotomy was performed after left pterional standard skin incision. Dura mater was opened and Sylvian dissection was started from distal to proximal. The possible attachments between the aneurysm neck and arachnoid mater covering the Sylvian fissure, and in the prevention of possible premature rupturing of the aneurysm during dissection, the neck of the aneurysm and M1 segment of the middle cerebral artery was brought to our point of view under the operating microscope during the early stage of the surgery (Figure 2). Our preoperatively planned goal as mentioned before was seen during the surgical intervention. Aneurysm was clipped and separated from the systemic circulation after the adequate dissection of the dome and neck. Laser Doppler flow meter was used to check complete closing of the aneurysm neck without the distortion of the related vascular structure. Topical papaverine was placed on

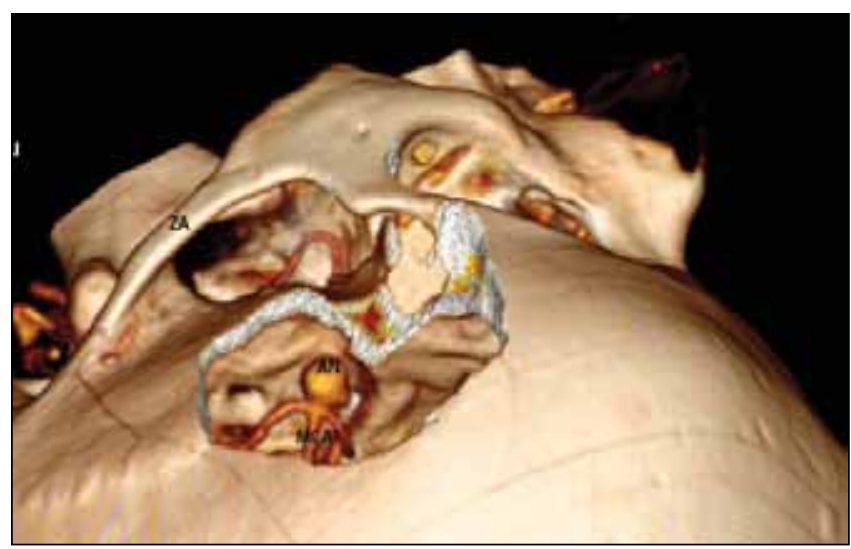

Figure 1: The preparation and estimation of head positions and head extension and angles in according to aneurysm position located at the middle cerebral artery bifurcation by using OsiriX MD computer software (ZA: Zygomatic arch, AN: Aneurysm, MCA: Middle cerebral artery).

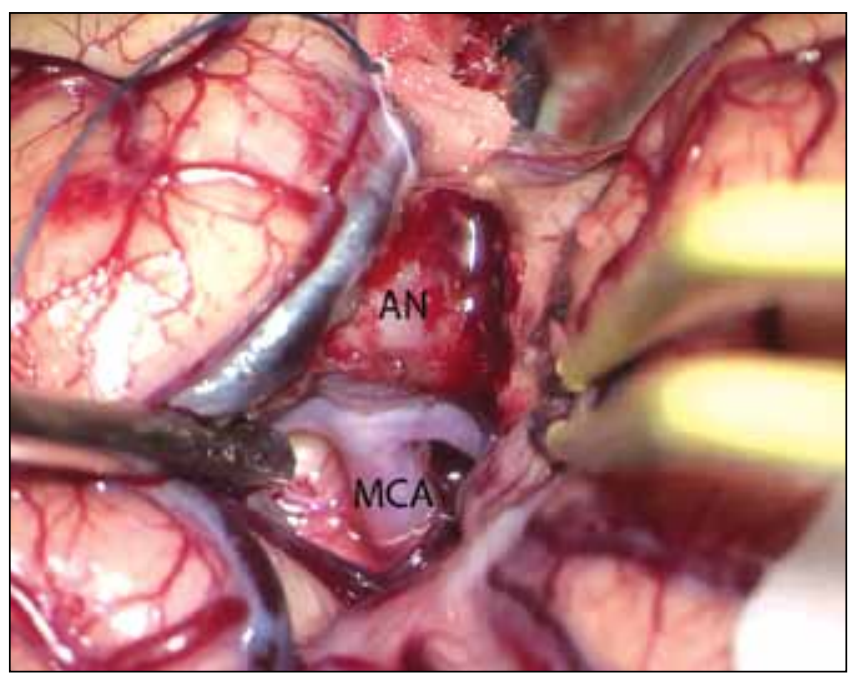

Figure 2: Operative photography shows the position and location of the aneurysm (AN: Aneurysm, MCA: Middle cerebral artery). the operative field, all layers were appropriately closed, and the surgery was concluded.

\section{DISCUSSION}

Yasargil described the details of standard head positioning for the patients with basal cerebral artery aneurysms in his classical monograph named "Microneurosurgery" (12). According to his original description, the position of the patient should be supine with the head at the foot end on a standard operating table. A three-point skeletal fixation device such as Mayfield-Kees should be placed at the foot of the table. A right-sided craniotomy should be preferred for mid-line as well as right-sided lesions for the right-handed surgeon (with some exceptions). The head should be directed about 20 degrees vertex down, elevated slightly, and rotated about 30 degrees to the left to bring the malar eminence to the superior point of the operating field. This positioning may cause inclining of the operative field slightly toward the surgeon and allow the frontal lobes to fall away from the orbital roof.

Digital Subtraction Angiography is still the most sensitive diagnostic procedure in the evaluation of intracranial vascular lesions such as aneurysms and arteriovenous malformations (9). At the same time, digital subtraction angiography is expensive, invasive, and leads to an associated significant morbidity and mortality risk of $1.5 \%$ to $2.0 \%$ (10). Computerized tomographic angiography with its three-dimensional advantage is commonly using diagnostic application for intracranial aneurysm detection and preoperative surgical planning. In the literature, the diagnostic sensitivity of computerized tomographic angiography was reported between the range of $70 \%$ and $96 \%$ depending on the size and location of the pathology $(3,7,8,11)$.

The volume rendering technique was first developed based on a research at the Mayo Clinic in the 1970s (1). Advances in image processing hardware and integration of new data manipulation techniques were then reported by the University of North Carolina and Pixar $(2,5)$. After this date, some important progressions were achieved in parallel with hardware and software advancement in the computer technology as well as image processing technology in neurological radiology. OsiriX is software for radiological image processing. Three-dimensional images can be created by using the software. The three-dimensional viewer provides modern rendering modes such as multiplanar reconstruction, surface rendering, volume rendering, and maximum intensity projection. In the present study, we used the OsiriX MD software for the processing of DICOM images. This software can show the basal cerebral arteries together with the bone structure of the cranial base. One can estimate the position of the sphenoid wing and M1 segment of the middle cerebral artery as well as the arterial bifurcation. At the same time, it is possible to give some degree of extension and lateral rotation of the head in the computer software. The position of the aneurysm, aneurysm neck and M1 trunk of the middle cerebral artery can be seen. The exploration of the M1 trunk 
has specific importance during surgery in terms of temporary clipping of the parent artery before clipping of the aneurysm neck for a safe surgery. Using this three-dimensional image processing software before the surgical intervention, the possible temporary site of $\mathrm{M} 1$ segment and the course and angle of the parent artery can be estimated.

\section{CONCLUSION}

Three-dimensional images of the head including bone and vascular structure together may give some specific dynamic information. Despite using the classical head position for aneurysm surgery, a case-specific head position based on the three-dimensional neuroradiological images produced by specific computer software such as OsiriX can be employed. Having the three-dimensional anatomical appearance of the location before the surgical intervention may also enhance the neuroanatomical interventional perspective of the surgeon. This program is safe and can be used for vascular neurosurgical cases.

\section{REFERENCES}

1. Calboun PS, Kuszyk BS, Heath DG, Carley JC, Fishman EK: Three-dimensional volume rendering of spiral CT data: Theory and Method. RadioGraphics 19(3): 745-763, 1999

2. Drebin RA, Carpenter L, Hanrahan P: Volume rendering. Comput Graph 22: 65-74, 1988

3. Karamessini MT, Kagadis GC, Petsas $T$, et al. CT angiography with three-dimensional techniques for the early diagnosis of intracranial aneurysms: Comparison with intraarterial DSA and the surgical findings. Eur J Radiol 49: 212-223, 2004
4. Kassel NF, Torner JC, Haley EC, Jane JA, Adams HP, Kongable $\mathrm{GL}$ : The international cooperative study on the timing of aneurysm surgery, I: Overall management results and, II: Surgical results. J Neurosurg 73:18-47, 1990

5. Levoy M: Display of surfaces from volume data. IEEE Comput Graph Applicat 8: 29-37, 1988

6. Miyaoka M, Sato K, Ishii S: A clinical study of the relationship of timing to outcome of surgery for ruptured cerebral aneurysms. J Neurosurg 79: 373-378, 1993

7. Schwartz RB, Tice HM, Hooten SM, et al: Evaluation of cerebral aneurysms with helical CT: Correlation with conventional angiography and MR angiography. Radiology 192:717-722, 1994

8. Teksam M, McKinney A, Casey S, et al: Multi-section CT angiography for detection of cerebral aneurysms. AJNR Am J Neuroradiol 25:1485-1492, 2004

9. Tomandi BF, Hammen T, Klotz E, Ditt H, Stemper B, Lell M: Bone-substraction $C T$ angiography for the evaluation of intracranial aneurysms. AJNR Am J Neuroradiol 27:55-59, 2006

10. Waugh JR, Sachara N: Arteriographic complications in the DSA era. Radiology 182: 243-246, 1992

11. White PM, Wardlaw JM, Easton V: Can noninvasive imaging accurately depict intracranial aneurysms? A systematic review. Radiology 217: 361-370, 2000

12. Yasargil MG: Microneurosurgery. Stutgart, New York: Georg Thieme Verlag, 1984: 215 